\title{
A New Badnavirus in Ribes Species, its Detection by PCR, and its Close Association with Gooseberry Vein Banding Disease
}

A. Teifion Jones and W. J. McGavin, Scottish Crop Research Institute, Invergowrie, Dundee DD2 5DA, Scotland, UK; A. D. W. Geering, Queensland Horticulture Institute, Department of Primary Industries, 80 Meiers Road, Indooroopilly, Queensland 4068, Australia; and B. E. L. Lockhart, Department of Plant Pathology, University of Minnesota, 495 Borlaug Hall, 1991 Upper Buford Circle, St. Paul 55108

\begin{abstract}
Jones, A. T., McGavin, W. J., Geering, A. D. W., and Lockhart, B. E. L. 2001. A new badnavirus in Ribes species, its detection by PCR, and its close association with gooseberry vein banding disease. Plant Dis. 85:417-422.

Gooseberry vein banding disease (GVBD) affects Ribes species and cultivars worldwide. It is the second most important virus-like disease in these crops after black currant reversion disease. In this paper, we describe a bacilliform virus, Gooseberry vein banding associated virus (GVBAV), which is associated closely with GVBD, and provide evidence that GVBAV is a distinct species within the genus Badnavirus. Purified GVBAV particles were ca. $120 \times 30 \mathrm{~nm}$ in size and contained dsDNA. The sequence of a $1.5-\mathrm{kb}$ DNA fragment amplified from viral genomic DNA was similar to those of a wide range of badnaviruses and contained motifs characteristic of the RNase $\mathrm{H}$ domain of the badnavirus open reading frame (ORF) III polyprotein. Phylogenetic analyses suggest that GVBAV is most closely related to Spiraea yellow leaf spot virus. Using sequence derived from the polymerase chain reaction (PCR)-amplified DNA fragment, virus-specific primers were designed. These primers were used in PCR to assay for GVBAV in a range of Ribes germplasm affected with GVBD, with other unrelated virus-like diseases and viruses found in Ribes, and in healthy plants. GVBAV was detected in all of 58 GVBD-affected plants from diverse sources, but not from healthy Ribes plants nor from plants infected with other viruses.
\end{abstract}

Additional keywords: black currant, red currant, Ribes uva-crispa, $R$. nigrum, R. rubrum

The two most common and most important virus-like diseases in commercial Ribes species worldwide are reversion in black currant $(R$. nigrum) (BCRD) $(3,11)$ and gooseberry vein banding (GVBD) in gooseberry (R. uva-crispa), red currant $(R$. rubrum), and black currant $(2,23$; A. T. Jones, unpublished data). The agent of BCRD is transmitted by the eriophyid gall mite, Cecidophyopsis ribis, and the causal agent is believed to be Blackcurrant reversion associated virus, genus Nepovirus (11,16-18).

In Ribes, GVBD is characterized by pronounced chlorosis of the lamina adjacent to the main veins of leaves (Fig. 1) (2) and is reported to cause significant reduction in the vigor and yield of some gooseberry cultivars (1). Symptoms are most evident in gooseberry and are much less noticeable, erratically distributed, or transient in black currant and red currant (2; A. T. Jones, unpublished data). The agent of GVBD is transmitted by aphids, mainly

Corresponding author: A. Teifion Jones

E-mail: tjones@scri.sari.ac.uk

Accepted for publication 14 December 2000.

Publication no. D-2001-0207-01R

(C) 2001 The American Phytopathological Society
Aphis grossulariae, Nasonovia ribisnigri, and Hyperomyzus spp. (2). van der Meer (30), and later Jones et al. (13), mechanically transmitted a virus with bacilliform particles from gooseberry affected with GVBD to Nicotiana occidentalis. Although van der Meer (30) considered these particles to be rhabdovirus-like, (13), were not enveloped and were ca. $130 \times 30 \mathrm{~nm}$ in size. These particles resemble more closely those of badnaviruses (Fig. 2) (13,14; F. A. van der Meer, personal communication). In examinations of ultrathin sections of GVBDaffected leaves of Ribes plants, the small bacilliform particles were not observed, but two other particle types were found (25). One had a particle morphology similar to rhabdoviruses, and the other had a particle morphology and induced ultrastructural changes typical of closthey, like those observed by Jones et al.

teroviruses (25). The causal agent(s) of GVBD therefore remains unknown.

In this paper we provide evidence that the small bacilliform virus is a badnavirus, which we have named Gooseberry vein banding associated virus (GVBAV). We also report the development of a polymerase chain reaction (PCR) assay to rapidly detect GVBAV in Ribes plants and, using this assay, show a strong correlation between GVBAV infection and GVBD.

\section{MATERIALS AND METHODS}

Plant material. The plant material used included the disease sources used previously $(6,14,25)$ together with a range of Ribes cultivars and species graft-inoculated with some of these disease sources. Additionally, a range of Ribes species and cultivars, identified as having or not having GVBD symptoms and obtained from different geographical locations worldwide, were acquired from the National Clonal Germplasm Repository, Corvallis, OR. The samples obtained were ca. 15-cm tips of dormant cane. Negative controls for PCR included tissue from healthy Ribes species and cultivars, as well as tissue from a range of plants affected with virus or viruslike disease symptoms other than those normally associated with GVBD, or infected with known viruses.

Virus transmission using dodder. Earlier studies demonstrated the transmission of a badna-like virus to Nicotiana occidentalis from GVBD-affected Ribes by mechanical inoculation of sap extracts, although transmission was very rare $(13,25,30)$. Attempts were therefore made to infect $N$. occidentalis using dodder (Cuscuta campestris). Dodder, raised from seed, was established on the gooseberry virus indicator B1385/81 (15) (referred to in this paper as VBI) showing strong symptoms of GVBD. Once established, the rapidly growing dodder strands were at-

Table 1. Sequences of polymerase chain reaction (PCR) primers used to detect Gooseberry vein banding associated virus and the predicted sizes of the amplified DNA

\begin{tabular}{lcc}
\hline Primer name & \multicolumn{1}{c}{ Primer sequence } & Size of product (bp) \\
\hline GVB1 - forward & 5' ACATCAAAGGGAAGGACAAC 3' & 407 \\
GVB 1 - reverse & 5' TCTAAAAGCATCCACTACCAC 3' & \\
GVB2 - forward & 5' TCAGACAGGCTCTCAACAATAC 3' & 309 \\
GVB2 - reverse & 5' TTCTAAAAGCATCCACTACCAC 3' & 527 \\
GVB3 - forward & 5' GACGATGAATCCCTGAGAACCC 3' & 527 GVB3 - reverse \\
\hline
\end{tabular}


tached to young plants of $N$. occidentalis, accessions 37B and P1. The dodder bridges, once established, were maintained for several weeks before PCR assays were done on young $N$. occidentalis leaves.

Attempts were also made to transmit virus by sap-inoculation from the dodder- bridged $N$. occidentalis plants to more $N$. occidentalis seedlings. PCR assays were made on these mechanically inoculated plants 2 to 5 weeks after mechanical inoculation.

Purification of GVBAV and isolation of its genomic DNA. To partially purify

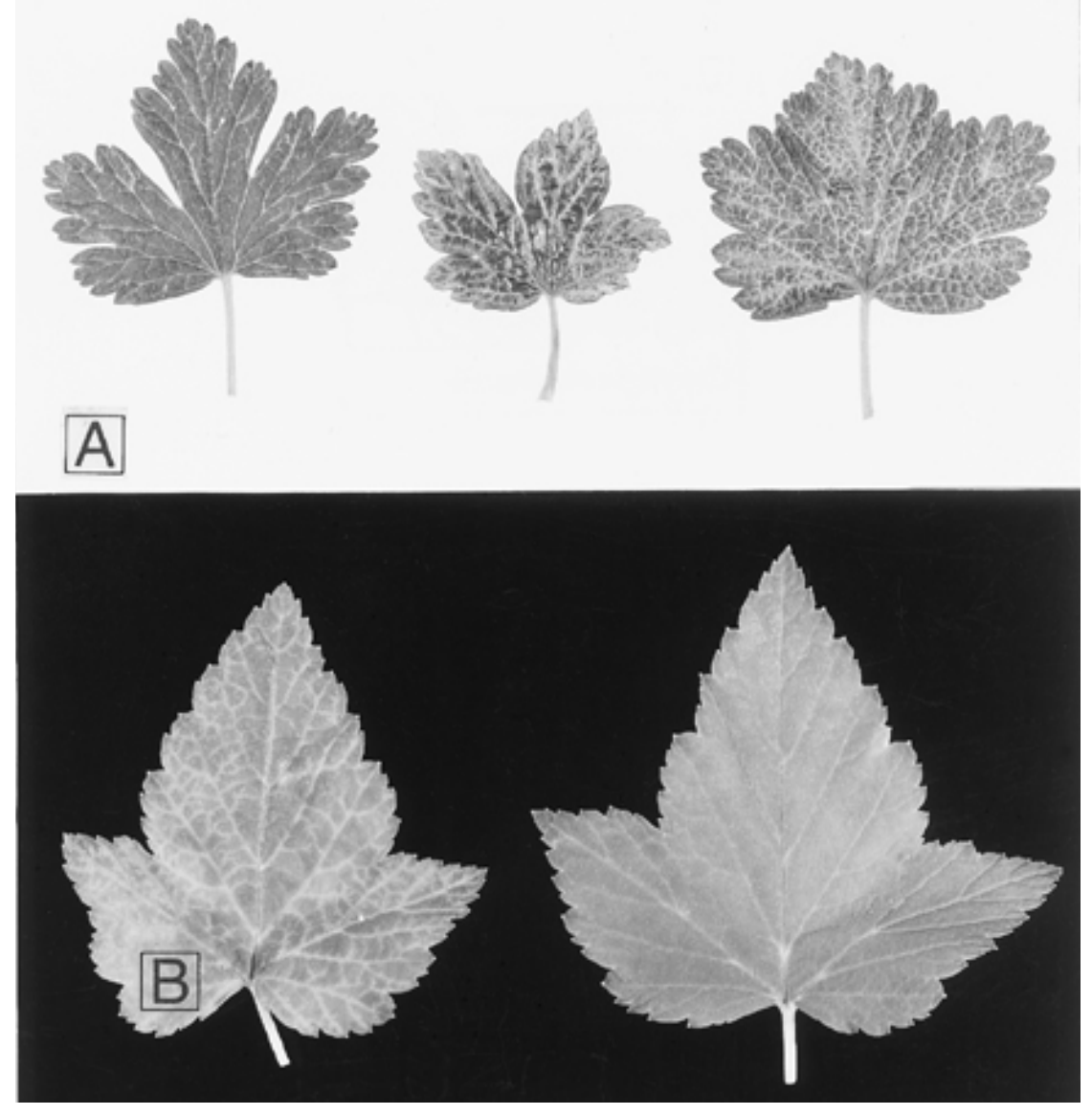

Fig. 1. Gooseberry vein banding disease symptoms in leaves of A, Ribes uva-crispa showing (left to right) increasing severity of veinbanding symptoms and $\mathbf{B}$, Ribes nigrum (left), and leaf from healthy plant (right).

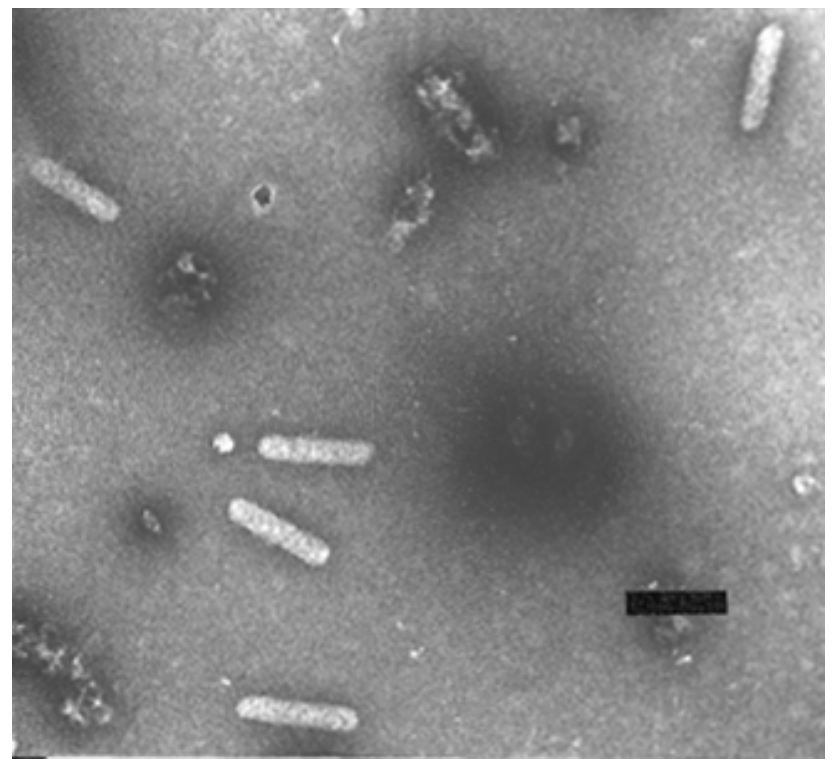

Fig. 2. Bacilliform particles of Gooseberry vein banding associated virus in a partially purified extract of gooseberry vein banding disease-affected Ribes uva-crispa leaves, negatively stained with $2 \%$ sodium phosphotungstate, $\mathrm{pH}$ 7.0. Bar represents $100 \mathrm{~nm}$.
GVBAV particles, diseased Ribes leaves were extracted $(1 \mathrm{~g}$ per $4 \mathrm{ml})$ in $500 \mathrm{mM}$ phosphate buffer, $\mathrm{pH} 7.5$, containing $1 \mathrm{M}$ urea, $4 \%(\mathrm{wt} / \mathrm{vol})$ polyvinylpyrrolidone (average molecular weight 40,000), and $0.5 \%$ ( $\mathrm{vol} / \mathrm{vol})$ 2-mercaptoethanol. The extract was filtered through muslin, and to the filtrate was added Triton $\mathrm{X}-100$ to a final concentration of $2 \%(\mathrm{vol} / \mathrm{vol})$. The mixture was kept at room temperature for $30 \mathrm{~min}$ or at $4^{\circ} \mathrm{C}$ overnight. After clarification by low speed centrifugation, the supernatant fluid was layered over a cushion of $30 \%(\mathrm{wt} / \mathrm{vol})$ sucrose in $100 \mathrm{mM}$ sodium-potassium phosphate buffer, $\mathrm{pH}$ 7.0, and centrifuged for $1 \mathrm{~h}$ at $148,000 \times g$ (max) in a Beckman 50.2 Ti rotor (Beckman Coulter, Fullerton, CA). For electron microscopy, virus particle preparations were stained in $2 \%(\mathrm{wt} / \mathrm{vol})$ sodium phosphotungstate, $\mathrm{pH} 7.0$, containing bacitracin at $150 \mu \mathrm{l} / \mathrm{ml}$.

For extraction of virus nucleic acid, purified virus particle preparations were centrifuged for $1 \mathrm{~h}$ at $148,000 \times g(\max )$ and the virus-containing pellets resuspended in a total of $250 \mu \mathrm{l}$ of $10 \mathrm{mM}$ Tris- $\mathrm{HCl}, 5 \mathrm{mM}$ $\mathrm{MgCl}_{2}, \mathrm{pH}$ 7.4. Following digestion with DNase and RNase to eliminate residual host plant nucleic acids, viral nucleic acid was prepared by treatment with proteinase $\mathrm{K}$, followed by phenol-chloroform extraction and ethanol precipitation as described previously (19).

Amplification, cloning, and sequencing of GVBAV DNA. PCR was done using the degenerate badnavirus primers BADNA2 and BADNAT (21) to amplify a portion of the GVBAV genome. The PCR mixture (final volume of $25 \mu \mathrm{l}$ ) contained $50 \mu \mathrm{M}$ each dNTP, $0.4 \mu \mathrm{M}$ each primer, 1.5 $\mathrm{mM} \mathrm{MgCl} 2,1.25$ units of Taq polymerase (Promega Corp., Madison, WI), 1× polymerase buffer, and $1 \mu \mathrm{l}$ of DNA. Amplification conditions were: 3 to 4 cycles at $94^{\circ} \mathrm{C}$ for $30 \mathrm{~s}, 37^{\circ} \mathrm{C}$ for $30 \mathrm{~s}$, and $72^{\circ} \mathrm{C}$ for $2 \mathrm{~min}$, and 25 cycles at $94^{\circ} \mathrm{C}$ for $30 \mathrm{~s}, 55^{\circ} \mathrm{C}$ for $30 \mathrm{~s}$, and $72^{\circ} \mathrm{C}$ for $2 \mathrm{~min}$.

The completed PCR was analyzed by electrophoresis in a 1\% agarose gel in $1 \times$ Tris-borate-EDTA, and the PCR-amplified DNA fragment was purified using a QIAEX II Gel Extraction Kit (QIAGEN, West Sussex, UK) according to manufacturer's instructions. This amplified DNA was then cloned using a Topo TA cloning kit (Invitrogen, Groningen, The Netherlands) according to the manufacturer's instructions. Plasmid DNA was purified using a QIAprep Spin Miniprep Kit (QIAGEN). Sequencing was done by the DNA Sequencing Facility at Iowa State University. To account for sequence errors introduced during PCR, three clones were sequenced and a consensus sequence was determined. The GVBAV sequence has been deposited in GenBank as Accession AF298883.

Sequence analyses. Additional sequences for analyses were (GenBank 
acession numbers given in parentheses): Banana streak virus strain Onne (BSVOnne; AJ002234) and strain Mysore (BSVMys; AF214005), Commelina yellow mottle virus (ComYMV; X52938) (22); Cacao swollen shoot virus (CSSV; L14546), Dioscorea bacilliform virus (DBV; X94576 and X94581), Rice tungro bacilliform virus (RTBV; D10774), Spiraea yellow leaf spot virus (SYLSV; AF299074), and Sugarcane bacilliform virus (SCBV; M89923) (5). Database searches were done using BLASTN (4). Protein sequence alignments were constructed using CLUSTALW (29), and the percent identity of pairwise combinations of sequences was calculated with DISTANCES (Genetics Computer Group Inc., Madison, WI). Phylogenetic analyses were done using the PHYLIP software package (J. Felsenstein, University of Washington, Seattle). When PROTPARS was used, the input order of sequences was randomized and jumbled three times. The robustness of the tree was assessed by bootstrap sampling of the multiple alignment (1,000 sets) using SEQBOOT, and a consensus tree was generated with CONSENSE. Virus-specific primers were designed using the program PRIME (Genetics Computer Group Inc., Madison, WI).

PCR using GVBAV-specific primers. DNA was isolated from the leaves of Ribes plants (in the early phase of the work) or from dormant buds using a DNeasy Plant Mini Kit (QIAGEN Ltd., Crawley, UK) according to the manufacturer's instructions. The primers used in PCR are shown in Table 1. PCR was done using a Readyto-go PCR Bead (Amersham Pharmacia Biotech, Uppsala, Sweden), to which was added $22 \mu \mathrm{l}$ of distilled water, $1 \mu \mathrm{l}$ of each primer $(10 \mu \mathrm{M})$, and $1 \mu \mathrm{l}$ of DNA template.

The PCR temperature conditions were optimized on a Hybaid PCR Express machine fitted with a temperature gradient block. The PCR conditions for GVB1 and GVB2 primers were: $95^{\circ} \mathrm{C}$ for $5 \mathrm{~min}$, then 30 cycles of $95^{\circ} \mathrm{C}$ for $1 \mathrm{~min}, 60^{\circ} \mathrm{C}$ for 1 min, $72^{\circ} \mathrm{C}$ for $1 \mathrm{~min}$, and then $72^{\circ} \mathrm{C}$ for 10 min. For GVB3 primers, the annealing temperature was elevated to $66^{\circ} \mathrm{C}$. The PCR products were analyzed by electrophoresis on a $4 \%$ polyacrylamide gel and stained with ethidium bromide (26).

\section{RESULTS}

Virus purification, characterization of virus nucleic acid, and PCR amplification. Virus was successfully purified from as little as $15 \mathrm{~g}$ of leaf tissue. Bacilliform particles, ca. $120 \times 30 \mathrm{~nm}$ in size, were observed by electron microscopy (Fig. 2). When nucleic acid from purified virus particles was examined by agarose gel electrophoresis, three electrophoretic species were detected (data not shown), similar to the three conformational forms described for badnavirus DNA $(19,20)$. These GVBAV nucleic acid species were completely digested by RNase-free RG1
DNase (Promega Corp., Madison, WI), but were undigested by DNase-free RNase and S1 nuclease (data not shown), showing that they were dsDNA. A single $1.5-\mathrm{kb}$ DNA fragment was amplified by PCR using the primers BADNA2 and BADNAT.

Sequence analyses. The PCR-amplified DNA fragment of GVBAV was cloned and
$\begin{array}{llllllllllllllllllll}\mathbf{Y} & \mathbf{I} & \mathbf{D} & \mathbf{D} & \mathbf{I} & \mathbf{L} & \mathrm{V} & \mathrm{E} & \mathrm{S} & \mathrm{N} & \mathrm{S} & \mathrm{L} & \mathrm{Q} & \mathrm{E} & \mathrm{H} & \mathrm{E} & \mathrm{S} & \mathrm{H} & \mathrm{L} & \mathrm{R}\end{array}$ TATATAGACGATATTCTCGTCTTCAGCAATTCCCTGCAGGAACATGAAAGCCATTTACGG

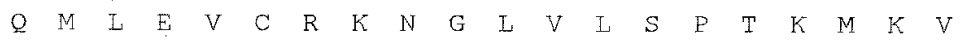
CAAATGCTTGAGGTTTGCAGGAAGAATGGGTTGGTGCTATCACCAACAAAAATGAAGGTT

$\begin{array}{llllllllllllllllllll}A & V & T & T & V & E & F & L & G & A & I & I & G & N & G & K & I & K & I & Q\end{array}$ GCTGTCACAACAGTGGAATTCCTAGGGGCCATCATCGGCAATGGGAAAATCAAGTTGCAG

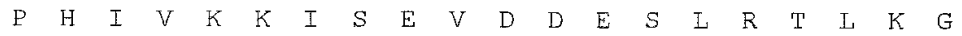
CCPCACATCGTCAAGAAGATTTCTGAAGTPGACGATGAATCCCTGAGAACCCTGAAAGGG

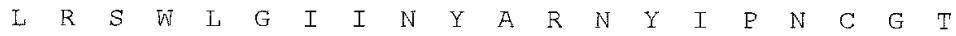
TTAAGAAGCTGGTTAGGCATAATCAACTATGCCAGGAATTACATTCCTAACTGTGGAACT

$\begin{array}{llllllllllllllllllllllllllllllll}I & L & G & P & L & Y & S & K & T & S & E & N & G & D & R & R & M & S & P & Q\end{array}$ TTGCTTGGTCCACT TTACAGCAAAACTAGCGAAAATGGGGATCGAAGAATGAGTCCTCAG

$\begin{array}{llllllllllllllllllll}\mathrm{D} & W & K & \mathrm{~L} & \mathrm{~V} & \mathrm{R} & \mathrm{K} & \mathrm{V} & \mathrm{K} & \mathrm{E} & \mathrm{L} & \mathrm{V} & \mathrm{K} & \mathrm{S} & \mathrm{L} & \mathrm{P} & \mathrm{D} & \mathrm{L} & \mathrm{E} & \mathrm{I}\end{array}$ GACTGGAAGCTGGTCAGGAAGGTCAAAGAGCTCGTCAAGAGTCTGCCAGACTTAGAGCTA

\begin{tabular}{lllllll|lllllllllllll}
$P$ & $P$ & $A$ & $G$ & $A$ & $Y$ & $V$ & $V$ & $I$ & $E$ & $T$ & $D$ & $G$ & $C$ & $M$ & $E$ & $G$ & $W$ & $G$ \\
\hline
\end{tabular} CCACCAGCAGGAGCCTATGTG ETCATCGAAACAGACGGCTGCATGGAAGGATGGGGAGGA

\begin{tabular}{llllllllllllll|llllllll}
$V$ & $C$ & $K$ & $W$ & $K$ & $H$ & $K$ & $K$ & $G$ & $E$ & $S$ & $A$ & $S$ & $A$ & $E$ & $K$ & $V$ & $C$ & $A$ & $Y$ \\
\hline
\end{tabular} GTGTGCAAATGGAAGCACAAGAAAGGAGAATCTGCCTCAGCAGAGAAAGTCTGCGCATAT \begin{tabular}{|lllll|llllllllllllll}
$A$ & $S$ & $G$ & $K$ & $E$ & $P$ \\
GCAAGTGGCAAATTCCCG & A & $I$ & $K$ & $S$ & $T$ & $I$ & $D$ & $A$ & $E$ & $M$ & $H$ & $G$ & $V$ & $M$ \\
\hline
\end{tabular}

$\begin{array}{llllllllllllllllllll}N & S & L & E & K & E & Q & I & Y & F & M & D & K & G & E & V & T & I & R & T\end{array}$ AACTCCCTGGAAAAATTCCAGATCTACT TCATGGACAAAGGTGAGGTCACCATCAGAACA

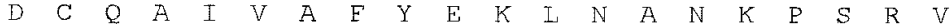
GACTGCCAGGCCATAGTAGCGTTCTACGAAAAGCTCAACGCTAATAAACCTTCGAGGGTT

$\begin{array}{lllllllllllllllllllll}R & W & \mathrm{~L} & \mathrm{~N} & \mathrm{E} & \mathrm{C} & \mathrm{D} & \mathrm{Y} & \mathrm{I} & \mathrm{T} & \mathrm{N} & \mathrm{T} & \mathrm{G} & \mathrm{V} & \mathrm{K} & \mathrm{V} & \mathrm{V} & \mathrm{F} & \mathrm{E} & \mathrm{H}\end{array}$ CGCTGGCTTAACTTCTGTGACTACATCACCAATACAGGAGTCAAGGTCGTCTT

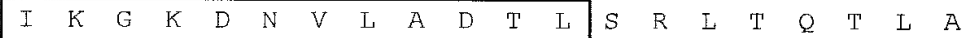
ATCAAAGGGAAGGACAACGTCCTAGCAGACACGCTCAGCCGACTCACACAGACCTTAGCT

$\begin{array}{llllllllllllllllllll}A & V & R & E & M & P & A & E & Q & E & E & I & L & R & Q & A & L & N & N & T\end{array}$ GCGGTTCGGGAGAT GCCCGCAGAACAGGAAGAGATCCTCAGACAGGCTCTCAACAATACT

$\begin{array}{llllllllllllllllllll}E & V & O & P & K & E & R & R & I & I & M & D & H & I & G & G & M & I & E & A\end{array}$ GAGGTCCAGCCCAAGGAACGAAGGATCCTCATGGATCACATCTGTGGAATGCTGGAAGCC

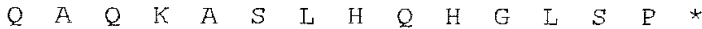

CAGGCCCAAAAGGCCAGTCTCCACCAACATGGGCTTAGCCCATGATCTATCTGATAATGG

AAGCTGACGCACCGGATGACTTCACCATAAATGATTCGTCATCACTTACGCCATCAGCTC

TATTATTACTTTACTTTTGTAAGTGCGTCAGTAGTGCGCTGAGTCAGGGAATCTTATCCC

1140

TTATGTCCTTTAGCCACACTTTCGGTGGTGGTGGATGCTTTTAGAACAAGCATTATTGTA

1200

AAAGCTAAGCTTTTGAGCTGTCGATGGGGCCCAATGAGCACCCGAGCTTCAAAACCTTAT

CTTCTACTCCCNATATAAGGAGTCTTAGGTAGAAGTAGAAAATCATCGAATAGCTTTCAT

1320

CGAAAACCTCTCACTTCTTT GTAAGCATTATTCCTCAATAAACAAATCTTCCGCAATACT

1380

CTGTTTCCTTTCTTMATTCTTTACTGTTACCTAGCCAGTCAGTAGAGAAGATCCACGAA

1440

Fig. 3. Nucleotide sequence of the polymerase chain reaction-amplified DNA fragment of Gooseberry vein banding associated virus. The predicted amino acid sequence is given above the nucleotide sequence. Sequence highlighted in bold corresponds to the BADNA2 primer. Boxed areas identify conserved motifs in the ribonuclease $\mathrm{H}$ domain of the badnavirus open reading frame (ORF) III polyprotein, previously identified by Medberry et al. (22) and Bouhida et al. (5). The putative TATA box is single underlined, and the putative polyadenylation signal is double underlined. 


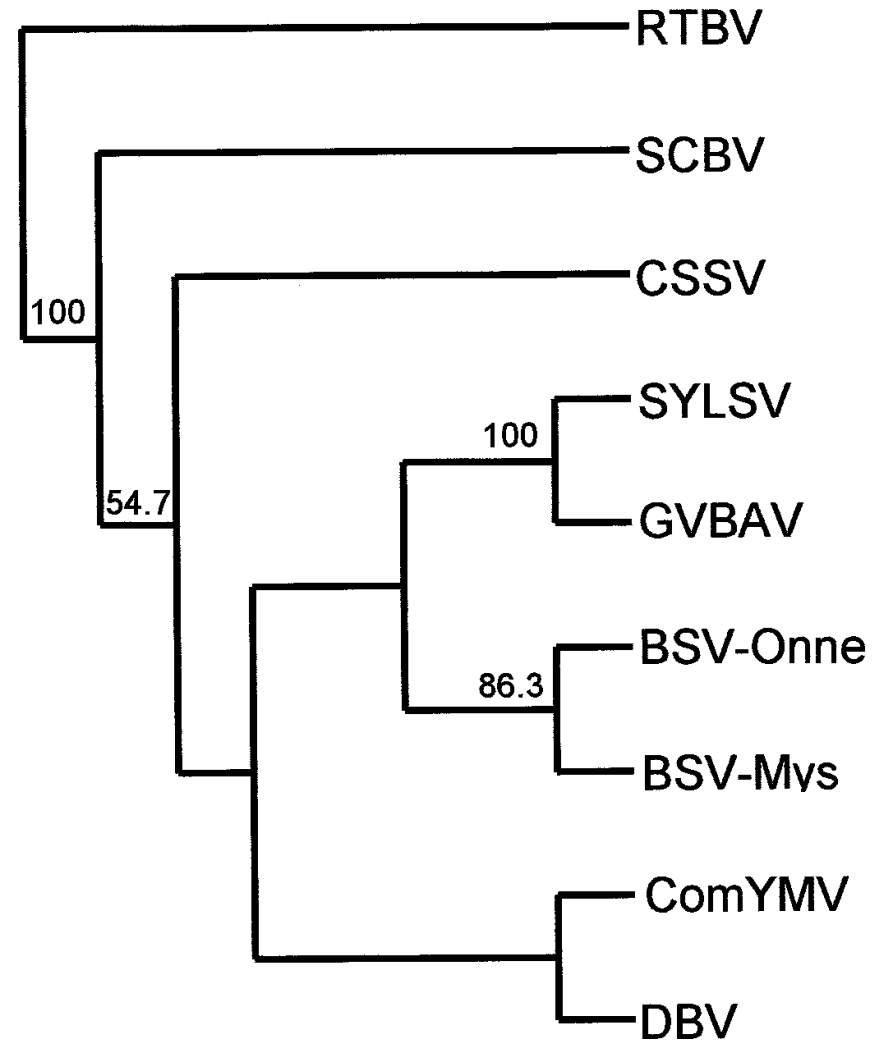

Fig. 4. Cladogram depicting the relationships of Gooseberry vein banding associated virus (GVBAV) to a range of other badnaviruses and Rice tungro bacilliform virus (RTBV). The badnaviruses are Banana streak virus isolates Onne and Mys (BSV-Onne and BSV-Mys), Cacao swollen shoot virus (CSSV), Commelina yellow mottle virus (ComYMV), Dioscorea bacilliform virus (DBV), Spiraea yellow leaf spot virus (SYLV), and Sugarcane bacilliform virus (SCBV). Relationships were investigated by parsimony, using the region of the open reading frame (ORF) III polyprotein corresponding to amino acid residues 7 to 274 (V to R) of the GVBAV sequence (Fig. 3). Bootstrap values of $50 \%$ or more are shown in the nodes of the branches.

Table 2. Detection of Gooseberry vein banding associated virus by polymerase chain reaction (PCR) assay in a range of plants affected with different viruses or viruslike diseases using three different primer sets

\begin{tabular}{|c|c|c|c|c|c|}
\hline \multirow[b]{2}{*}{ Species } & \multirow[b]{2}{*}{ Cultivar } & \multirow{2}{*}{$\begin{array}{c}\text { Diseases and } \\
\text { viruses }^{\mathrm{a}}\end{array}$} & \multicolumn{3}{|c|}{ PCR result ${ }^{b}$} \\
\hline & & & GVB1 & GVB2 & GVB3 \\
\hline \multirow[t]{2}{*}{ Ribes uva-crispa } & VBI indicator & GVBD & +++ & +++ & +++ \\
\hline & Invicta & BYD & - & - & - \\
\hline \multirow[t]{14}{*}{ Ribes nigrum } & Amos Black & GVBD & + & + & + \\
\hline & Baldwin & GVBD & + & + & + \\
\hline & Ben Lomond & GVBD & +++ & +++ & +++ \\
\hline & Ben More & GVBD & + & ++ & + \\
\hline & Ben Nevis & GVBD & +++ & +++ & +++ \\
\hline & Ben Tron & GVBD & ++ & ++ & ++ \\
\hline & Laxton & GVBD & ++ & ++ & ++ \\
\hline & Ben Sarek & AlMV & - & - & - \\
\hline & Ben Nevis & ArMV & - & - & - \\
\hline & Ben More & BIVD & - & - & - \\
\hline & Ben Tron & BIVD & - & - & - \\
\hline & Ben More & BYD & - & - & - \\
\hline & Ben Tron & BYD & _- & - & _- \\
\hline & Ben Lomond & BRD & - & - & - \\
\hline \multirow[t]{2}{*}{ Ribes species } & R. divaricatum & GVBD & +++ & +++ & +++ \\
\hline & R. petrium & GVBD & +++ & +++ & +++ \\
\hline \multirow[t]{2}{*}{ Rubus idaeus } & Malling Promise & RLMV & - & - & - \\
\hline & Glen Clova & RLSV & - & - & - \\
\hline
\end{tabular}

${ }^{\text {a }}$ GVBD = gooseberry vein banding disease; ArMV = Arabis mosaic virus; AlMV = Alfalfa mosaic virus; $\mathrm{BIVD}=$ blackcurrant infectious variegation disease; $\mathrm{BYD}=$ blackcurrant yellows disease; $\mathrm{BRD}=$ blackcurrant reversion disease; RLMV = Raspberry leaf mottle virus; RLSV $=$ Raspberry leaf spot virus.

${ }^{\mathrm{b}}+$ indicates a positive PCR result $(++,+++$ indicate increasing yields of PCR product); - indicates a negative PCR result. All tests were made on buds except for VBI indicator, in which buds and leaves were used. sequenced (Fig. 3). When this sequence was compared against GenBank using BLASTN, highly significant matches were observed with badnaviruses such as BSV and ComYMV, suggesting homology. The deduced protein sequence contained motifs characteristic of the RNase $\mathrm{H}$ domain of the open reading frame (ORF) III polyprotein of all badnaviruses and RTBV. A putative TATA box, a component of the badnavirus promoter, was found downstream of the protein-coding region. Present also was a consensus sequence for a eukaryotic polyadenylation signal (AATAAA).

When GVBAV was compared with RTBV and a range of recognized and tentative members of the genus Badnavirus, GVBAV was found to be most closely related to SYLSV (Fig. 4). The close relationship of GVBAV to SYSLV was strongly supported with a bootstrap value of $100 \%$. In the region of comparison, there was $79.5 \%$ amino acid (aa) sequence identity between the two viruses. By comparison, the two BSV isolates (BSV-Mys and BSV-Onne) had $74.7 \%$ aa sequence identity, and ComYMV and DBV had $65.3 \%$ aa sequence identity.

PCR detection of GVBAV using virusspecific primers. In assays on a range of healthy and diseased cultivars of $R$. $u v a$ crispa and $R$. nigrum, GVBAV was detected only in plants showing symptoms of GVBD, and not in plants affected by other virus-like diseases, nor in healthy plants (Table 2, Fig. 5). This suggests a close association of GVBAV infection with GVBD.

To determine the consistency and reliability of the PCR assay for GVBAV and to assess further the association of GVBAV with GVBD, assays were made on a wide range of Ribes species and cultivars obtained from the National Germplasm Repository, Corvallis, OR. Of the 51 samples received, 48 were reported to be affected with GVBD and three were of unknown GVBD status. Using primer set GVB1, GVBAV was detected in 47 of the 48 GVBD-affected samples and in two of the three plants of unknown GVBD status $(R$. rubrum cv. White Transparent and $R$. nigrum ID 215). GVBD samples testing positive for GVBAV included $R$. uva-crispa cvs. Blood Hound, Columbus, Early Sulphur, Emerald, Fascination, Gem, Guido, Guy's Seedling, Howard's Lancer, Lancashire Lad, Lord Elco, Surprise, Trumpeter, and Weisse Volltragende; $R$. nigrum cvs. Ben More, Blacksmith, Westwick Choice, and Westwick Triumph; the R. rubrum cvs. Comet, Fay (ID 20), Fay (ID 463), Fillbasket, Laxton No. 1, Minnesota 52, Minnesota 69, New York 53, New York 72, North Star, Prince Albert, Raby Castle, Rosa Hollandische, Rosetta, Stephens, Tatran, Versailles, Weisse Aus Juteborg, White Imperial, and Zitaxia; and the wild species, $R$. dicantha, $R$. lacustre, $R$. maximowiczii, 
$R$. orientale (IDs 271, 390, and 396), $R$. pauciflorum, and $R$. sanguineum (IDs 144 and 446) (Fig. 5). Several of these samples tested positive by PCR only after the volume of template was increased from 1 to 3 $\mu \mathrm{l}$, suggesting that template concentration was limiting. The $R$. rubrum cv. Minnesota 71 , reported to be affected with GVBD, and $R$. nigrum cv. Beech Tree Nestling of unknown GVBD status, did not index positive for GVBAV in three separate PCR assays using primer set GVB1 (Fig. 5).

These data, together with those in Table 2 , confirm the very close association of GVBD with GVBAV. However, this association was not complete for the GVBDaffected $R$. rubrum cv. Minnesota 71, in which GVBAV was not detected. To explore the possibility of limiting virus concentration and/or of a virus sequence variant in this sample, DNA extracts were assayed by PCR using $3 \mu \mathrm{l}$ instead of $1 \mu \mathrm{l}$ of target DNA and 35 instead of 30 cycles of amplification, using all three GVB primer sets. Known GVBAV positive and negative samples were included for comparison. Table 3 shows that DNA of the expected size was amplified from all GVBD-affected samples with one or more of the three primer sets, confirming further the very close association of this virus with GVBD. However, DNA was amplified from cv. Minnesota 71 using only primer set GVB3, and no product was detected from cv. Beech Tree Nestling (of unknown GVBD status) using all three primer sets (Table 3). The results support the hypothesis that the previous failure to detect GVBAV in cv. Minnesota 71 with the GVB1 primers was due to sequence variation in the region of the virus genome from which the primers were designed. It also suggests that cv. Beech Tree Nestling is not infected with GVBAV and it is not recorded as showing GVBD symptoms. The correlation between the presence of GVBAV and GVBD appears therefore to be complete.

GVBAV was also detected, although weakly, in N. occidentalis plants connected via dodder strands to gooseberry affected with GVBD, but it was not detected in the dodder strands connecting the plants to the infected gooseberry. GVBAV was not detected in $N$. occidentalis plants inoculated with sap from the $N$. occidentalis plants infected via dodder (data not shown). No symptoms developed in any of the dodderbridged $N$. occidentalis plants and, unlike in earlier studies of infected plants (13), no GVBAV particles were detected by electron microscopy of sap extracts.

\section{DISCUSSION}

In this paper we have provided evidence that GVBAV is a badnavirus. We base this conclusion on particle morphology, the dsDNA genome, and the significant sequence similarity to other members of the virus genus. The results of a phylogenetic analysis suggest that GVBAV is most closely related to SYLSV, another tentative member of genus Badnavirus. The two viruses also share biological properties. Both viruses infect temperate plants, whereas all previously described badnaviruses have been found in tropical or subtropical plants. Whereas mealybugs are the main vectors of badnaviruses, aphids transmit SYLSV (20) and the causal agent of GVBD (2), probably in a semipersistent manner. Some caution should be exercised in the placement of GVBAV in the genus Badnavirus without complete examination of the genome organization. RTBV has been split from the genus Badnavirus, based partly on the presence of a fourth open reading frame (ORF IV), and the fact that the virus is transmitted by leafhoppers
(24). However, GVBAV appears dissimilar to RTBV, both in nucleotide sequence and in the absence of an ORF comparable to ORF IV of RTBV.

Despite the close association of GVBAV with GVBD, further work is required to determine if this virus is the cause of the disease because GVBAV has not been returned to Ribes plants to reproduce the disease symptoms (fulfilling Koch's postulates). Furthermore, in addition to GVBAV, rhabdovirus-like and closterovirus-like particles have also been found in GVBD-affected plants (25), and the role, if any, of these other viruses in inducing the disease is not known. By analogy, the raspberry veinbanding mosaic disease complex in Rubus is caused by dual infection of an aphid-borne virus and Rubus

\section{0}

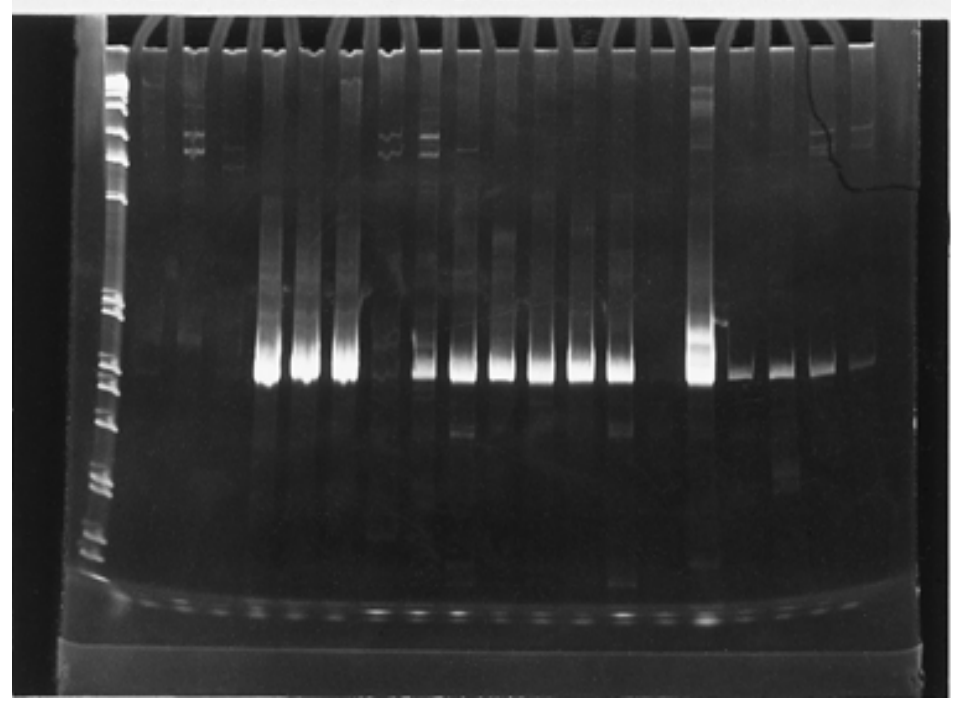

Fig. 5. Polyacrylamide gel electrophoresis of polymerase chain reaction (PCR) products generated from DNA extracts from Ribes species and cultivars using the GVB1 primer set and 30 cycles of amplification. The gel was stained in ethidium bromide. Lanes contain: (1) molecular size markers, (2) water control, (3) healthy gooseberry, (4 to 20) cvs. Beech Tree Nestling, Blood Hound, Early Sulphur, Gem, Blacksmith, Westwick, Weisse, White Imperial, Comet, Laxton No. 1, Minnesota 52, Minnesota 71, Prince Albert, Rosetta, Ribes diantha, $R$. lacustre, and $R$. nigrum, respectively. In this assay, cvs. Beech Tree Nestling (lane 4), Blacksmith (lane 8), and Minnesota 71 (lane 15) each failed to produce a PCR product of the correct size, but in further assays cv. Blacksmith did produce a Gooseberry vein banding associated virus-specific product.

Table 3. Assays for Gooseberry vein banding associated virus by polymerase chain reaction (PCR) in buds of healthy and diseased Ribes species and cultivars using three different primer sets

\begin{tabular}{|c|c|c|c|c|c|}
\hline \multirow[b]{2}{*}{ Species } & \multirow[b]{2}{*}{ Cultivar } & \multirow{2}{*}{$\begin{array}{l}\text { Disease } \\
\text { status }^{\mathbf{a}}\end{array}$} & \multicolumn{3}{|c|}{ PCR result ${ }^{b}$} \\
\hline & & & GVB1 & GVB2 & GVB3 \\
\hline \multirow[t]{3}{*}{ Ribes uva-crispa } & Beech Tree Nestling & Unknown & - & - & - \\
\hline & Guy's Seedling & GVBD & +++ & +++ & +++ \\
\hline & $\operatorname{Pax}$ & Healthy & - & - & - \\
\hline Ribes nigrum & Black Smith & GVBD & ++ & + & ++ \\
\hline \multirow[t]{4}{*}{ Ribes rubrum } & Minnesota 71 & GVBD & - & - & ++ \\
\hline & Rosetta & GVBD & ++ & ++ & +++ \\
\hline & Tatran & GVBD & + & + & + \\
\hline & White Transparent & GVBD & + & + & + \\
\hline \multicolumn{2}{|c|}{ Ribes nigrum (215) } & Unknown & ++ & + & + \\
\hline \multicolumn{2}{|c|}{ Ribes orientale (396) } & GVBD & + & + & + \\
\hline \multicolumn{2}{|c|}{ Ribes sanguineum (144) } & GVBD & ++ & +++ & + \\
\hline \multicolumn{2}{|c|}{ Ribes sanguineum (446) } & GVBD & + & + & + \\
\hline
\end{tabular}

${ }^{a}$ GVBD = Gooseberry vein banding disease.

$\mathrm{b}+$ indicates a positive PCR result $(++,+++$ indicate increasing yields of PCR product); - indicates a negative PCR result. 
yellow net virus (RYNV), another aphidborne virus with characteristics of the genus Badnavirus $(8,12,27,28)$.

In our assays, the ability to detect GVBAV varied among Ribes species, being detected much more readily in cultivars of $R$. uva-crispa and $R$. rubrum than in $R$. nigrum and most wild Ribes species (Table 2). These differences in the ease of detecting GVBAV by PCR may reflect differences between plant species in virus titers and/or differences in the quality and quantity of DNA extracted from their tissues. However, detection by PCR of GVBAV varied significantly in different cultivars of $R$. nigrum graft-inoculated with the same virus isolate (Table 2). This variation in the sensitivity of detection may reflect variation in virus titers, uneven distribution of the virus within plants, as occurs for BRAV in black currant (16), or intermittent replication of the virus over time, as occurs for BSV in bananas (7).

The PCR assay using the GVB1 primers was quite robust, allowing detection of GVBAV in 47 of the 48 GVBD samples received from the U.S. germplasm collection. The remaining sample tested positive by PCR assay with the GVB3 set of primers (Table 3). The failure of this isolate to be detected with the GVB1 primers suggests that there is some sequence variability among isolates, although the extent of the variation was not determined. This problem of sequence variability might be overcome by combining primers in a duplex PCR assay. Alternatively, more conserved regions of the genome could be targeted for design of the primers.

The sensitivity of PCR also allowed detection of GVBAV in N. occidentalis plants attached to a GVBD-affected gooseberry plant by dodder. This result confirms earlier data, based on mechanical transmission experiments, that showed this species to be a host of the virus $(13,25,30)$. However, the PCR product from infected $N$. occidentalis plants was weak, suggesting that the titer of GVBAV was very low. This may explain the great difficulty both of infecting $N$. occidentalis plants with GVBAV and of maintaining this virus in these plants by sequential transfer of sap extracts $(13,25)$. In one assay, we failed to detect GVBAV in the dodder stems connecting the infected gooseberry to the $N$. occidentalis plants, suggesting that, as with several different viruses, dodder acts only as a passive vascular bridge between the plants and is not infected with the virus (10).

The optimized PCR protocols reported here allow rapid, reliable, and sensitive means of detecting GVBAV, and hence GVBD, in a wide range of Ribes germplasm. Currently, the only means of detecting GVBD is either by the expression of symptoms in plants, which in $R$. nigrum and $R$. rubrum are often very mild or transient, or by graft-inoculation to sensitive indicator plants (9). Such graft assays are laborious and require more than 9 months to complete. PCR assay therefore offers a significant saving in time and labor. Furthermore, because GVBAV was detected in dormant buds, assessments can be made outside the growing season and before natural plant growth occurs, providing a useful application for plant introduction and quarantine programs.

\section{ACKNOWLEDGMENTS}

We thank Joseph Postman, National Clonal Germplasm Repository, Corvallis, OR, for providing many of the Ribes samples tested. Studies on nonindigenous viruses were done under the conditions of a license from the Scottish Executive Rural Affairs Department (SERAD). Work at SCRI is grant aided by the SERAD.

\section{LITERATURE CITED}

1. Adams, A. N. 1979. The effect of gooseberry vein banding virus on the growth and yield of gooseberry and red currant. J. Hortic. Sci. 54:23-25.

2. Adams, A. N., and Posnette, A. F. 1987. Gooseberry vein banding. Pages $129-130$ in: Virus Diseases of Small Fruits. R. H. Converse, ed. U.S. Dep. Agric. Agric. Handb. 631.

3. Adams, A. N., and Thresh, J. M. 1987. Reversion of black currant. Pages 133-136 in: Virus Diseases of Small Fruits. R. H. Converse, ed. U.S. Dep. Agric. Agric. Handb. 631.

4. Altschul, S. F., Gish, W., Miller, W., Myers, E. W., and Lipman, D. J. 1990. Basic local alignment search tool. J. Mol. Biol. 215:403410 .

5. Bouhida, M., Lockhart, B. E. L., and Olszewski, N. E. 1993. An analysis of the complete sequence of a sugarcane bacilliform virus genome infectious to banana and rice. J. Gen. Virol. 74:15-22

6. Cox, S., Mayo, M. A., and Jones, A. T. 2000. The occurrence of dsRNA species in apparently healthy and virus-infected Ribes cultivars, and evidence that one such species originates from a member of the virus family Totiviridae. Eur. J. Plant Pathol. 106:353-364.

7. Dahal, G., Pasberg-Gauhl, C., Gauhl, F., Thottappilly, G., and Hughes, J. d'A. 1998. Studies on a Nigerian isolate of banana streak badnavirus: II. Effect of intraplant variation on virus accumulation and reliability of diagnosis by ELISA. Ann. Appl. Biol. 132:263275.

8. Jones, A. T. 1991. Rubus host range of rubus yellow net virus and its involvement with other aphid-borne latent viruses in inducing raspberry veinbanding mosaic disease. Ann. Appl. Biol. 118:331-338.

9. Jones, A. T. 1992. Appendix I. Recommended indexing procedures for detecting viruses, viroids, mycoplasma-like and rickettsia-like organisms, and virus-like diseases in small fruit crops. Acta Hortic. 308:145-166.

10. Jones, A. T. 1993. Experimental transmission of viruses in diagnosis. Pages 49-72 in: Diagnosis of Plant Virus Diseases. R. E. F. Matthews, ed. CRC Press, Boca Raton, FL.

11. Jones, A. T. 2000. Black currant reversion disease - The probable causal agent, eriophyid mite vectors, epidemiology and prospects for control. Virus Res. 71:71-84.

12. Jones, A. T., McGavin, W. J., Geering, A. D. W., and Lockhart, B. E. L. 2001. Detection by PCR of viruses in Rubus and Ribes species. Acta Hortic. In press.

13. Jones, A. T., McGavin, W. J., and Watkins, C. A. 1992. Recent studies in Scotland on the aetiology of virus and virus-like diseases of small fruit crops. Acta Hortic. 308:31-35.

14. Jones, A. T., and Roberts, I. M. 1976. Ultra- structural changes and small bacilliform particles associated with infection by rubus yellow net virus. Ann. Appl. Biol. 84:305-310.

15. Knight, V. H. 1985. A new indicator for gooseberry vein banding virus. Plant Pathol. 34:629-631.

16. Latvala, S., Susi, P., Lemmetty, A., Cox, S., Jones, A. T., and Lehto, K. 1997. Ribes host range and erratic distribution within plants of blackcurrant reversion associated virus provides further evidence for its role as the causal agent of reversion disease. Ann. Appl. Biol. 131:283-295.

17. Lemmetty, A., Latvala, S., Jones, A. T., Susi, P., McGavin, W. J., and Lehto, K. 1997. Purification and properties of a new virus from black currant, its affinities with nepoviruses, and its close association with black currant reversion disease. Phytopathology 87:404413.

18. Lemmetty, A., and Lehto, K. 1999. Successful back-inoculation confirms the role of black currant reversion associated virus as the causal agent of reversion disease. Eur. J. Plant Pathol. 105:297-301.

19. Lockhart, B. E. L. 1990. Evidence for a double-stranded circular DNA genome in a second group of plant viruses. Phytopathology 80:127-131.

20. Lockhart, B. E. L., and Lachner, J. 1999. An aphid-transmitted badnavirus associated with yellow leafspot of spiraea. Phytopathology 89:S46.

21. Lockhart, B. E. L., and Olszewski, N. E. 1993. Serological and genomic heterogeneity of banana streak badnavirus: Implications for virus detection in Musa germplasm. Pages 105-113 in: Breeding Banana and Plantain for Resistance to Diseases and Pests. J. Ganry, ed. CIRAD/INIBAP, Montpellier, France.

22. Medberry, S. L., Lockhart, B. E. L., and Olszewski, N. E. 1990. Properties of Commelina yellow mottle virus's complete DNA sequence, genomic discontinuities and transcript suggest that it is a pararetrovirus. $\mathrm{Nu}-$ cleic Acids Res. 18:5505-5513.

23. Postman, J. D. 1993. Expanded geographic and host range of vein-banding disease of Ribes. Plant Dis. 77:953.

24. Pringle, C. R. 1998. The universal system of virus taxonomy of the International Committee on Virus Taxonomy (ICTV), including new proposals ratified since publication of the Sixth ICTV Report in 1995. Arch. Virol. 143:203-210.

25. Roberts, I. M., and Jones, A. T. 1997. Rhabdovirus-like and closterovirus-like particles in ultrathin sections of Ribes species with symptoms of blackcurrant reversion and gooseberry veinbanding diseases. Ann. Appl. Biol. 130:77-89.

26. Sambrook, J., Fritsch, E. F., and Maniatis, T. 1989. Molecular Cloning Laboratory Manual, 2nd ed. Cold Spring Harbor Laboratory, Cold Spring Harbor, NY.

27. Stace-Smith, R. 1956. Studies on Rubus virus diseases in British Columbia. III. Separation of the components of raspberry mosaic. Can. J. Bot. 34:435-442.

28. Stace-Smith, R., and Jones, A. T. 1987. Rubus yellow net virus. Pages 175-178 in: Virus Diseases of Small Fruits. R. H. Converse, ed. U.S. Dep. Agric. Agric. Handb. 631.

29. Thompson, J. D., Higgins, D. G., and Gibson, T. J. 1994. Clustal W: Improving the sensitivity of progressive multiple sequence alignment through sequence weighting, position specific gap penalties and weight matrix choice. Nucleic Acids Res. 22:4673-4680.

30. van der Meer, F. A. 1989. Nicotiana occidentalis, a suitable test plant in research on viruses of small fruit crops. Acta Hortic. 236:27-35. 